\title{
Reflections on the Death Scene
}

\author{
BRUCE BuChan, MARgaret GibSON \\ AND DAVID ELLISON \\ GRIFFITH UNIVERSITY
}

The essays in this issue of Cultural Studies Review approach the phenomenon of human mortality through analysis of the scene of death. The death scene is used as a way of interrogating mortality, of considering its representation, the memorialisation of death, the legal and medical constraints on the dying, and the moral and political questions posed by the fact of death. Studies of mortality have long been a staple of work in the humanities and social sciences. The novelty of this collection lies in the close attention given to the exploration of the layers of meaning ascribed to the scene of death. Indeed, the iconographic history of the scene of death in the arts and sciences allows us to speak of the death scene as a trope grounded in lived history and representational practice. ${ }^{1}$ Known through witness and thus at one remove, the death scene in its varied representational forms existentially and morally engages the human subject in imagining what it might be like to have died in this or that way, learning too, perhaps, the moral conduct, emotional and spiritual demeanour expected of the dying and those in witness. 
In its myriad forms of ritual and convention the death scene supplies meaning at the margins of the annihilating unrepresentability of death itself-an adjacent philosophical problem for Epicurus and onwards, through Freud, Blanchot, Derrida and Damien Hirst. The death scene is inherently dramatic in that it presupposes the presence of persons who witness something-a scene-that enrols those present in tragedy, epic, black comedy, allegory, pastoral or passion play as the circumstances dictate. Not only is the death scene a means to extract a coda of sorts from the cessation of a given life, it is also a potent means of summary. Histories can be woven from a handful of selected deaths. Here is one iteration of Western modernity: Charles I, Louis XVI, Lincoln, Arch Duke Franz Ferdinand, the Romanovs, Eichmann, the Kennedys, Martin Luther King. Each of these scenes-of figures dying at the scaffold, in a state box, a cellar, limousines, a hotel kitchen or a motel balcony-speaks inexhaustibly to the time and place of that death and the transformative events that may be claimed to issue from it. Of course, death scenes are not the exclusive domain of the powerful, they are our common fate. One of the debates that preoccupies our moment, and forms the subject for several of the essays in this issue, is precisely what kind of death scene can we offer the dying? Not surprisingly that question impinges upon, and gives shape and purpose to, arguments about the kinds of death we the living are prepared to tolerate, imagine or realise.

Social historians of death and dying in Western culture have explored the impact of medical knowledge, technology and practice in altering the experience of dying for the dying and for those in support and witness. In the 1880s, British workhouse hospitals began screening the beds of the dying in accordance with local government board regulations. These recommended the use of 'two or three screens (on wheels) large enough to completely surround a bed when a patient is being bathed in the ward, or is very ill or dying'. ${ }^{2}$ What begins here with the treatment of the most socially powerless gradually extends outwards to broadly encompass the experience of modern death: cellular, private, curtained, individualised and obscured. In the second half of the twentieth century, death was largely displaced from the home and the bedroom (where doctor, nurse, priest, family, friends and servants might be in attendance) to that of the hospital and the public hospital bed. ${ }^{3}$ In 'The Storyteller', Walter Benjamin writes: 'There used to be no house, hardly a 
room, in which someone had not once died. ${ }^{4}$ Writing on the domestic scene of death in the Victorian age, Michael Wheeler notes the importance of the bed itself in previous centuries where family property might have an extensive intergenerational history:

In everyday life, as well as in religious epic poems, the bed in which a woman died might well have been that in which she had conceived and given birth to her children. In a less mobile society than our own, this same bed might even have been a family heirloom, in which she herself had been conceived and born. ${ }^{5}$

Occupied by both the living and dying, the hospital bed and room is a general and impersonal setting-a borrowed space of transition rather than belonging. Through the palliative care movement and the broad sociological critique of medical dominance, the space of home has been reevaluated in social policy and practice in Australia as a place for medical and/or therapeutic support systems for the dying and their carers. This recent historical reemergence of the home as a communal, professionally supported place for dying is examined in John Rosenberg's essay in this special issue. Deborah Parker also focuses on the place of death. In 'Residential Aged Care Facilities: Places for Living and Dying' she discusses key aspects of her ethnographic study of residential care homes in Adelaide, Australia. Among other things, Parker's essay focuses on the spatial separation of the living and the dying in residential care, and how objects such as aromatherapy burners and CD players are placed within rooms to symbolise to staff at all levels that a death is imminent. As the process of dying retreated into the privacy of nursing homes and hospitals, the once widespread use of photography to document the dead entered into a period of long dormancy that has only recently been challenged. In 'Death and Digital Photography', Helen Ennis explores how a highly flexible and spontaneous form of technology_digital photography-overcame prohibitions on visualising death and dying as well as enabling emergent networks of mourning mapped onto existing globalised social media.

Since the mid nineteenth century, the governance of death in Western countries has involved a 'top-down' structure of public health approaches to the control of diseases through management of the built environment (particularly waste and water) and populations within that environment. 'By mid-Victorian times 
in the UK', Kellahear writes, 'new quarantine laws were passed; homes of the diseased or deceased disinfected, individuals removed to hospitals on warrant, and medical officers given power to close schools or shops thought to breed germs or infectious diseases'. ${ }^{6}$ The impact of scientific knowledge on the control of disease through the management of the social body has displaced a sense of its potential proximity wherever there is human life. The central place of medical technology in extending and promoting biological life where it would otherwise fail without its use is a major aspect of twenty-first-century governance of death and dying.

The medico-legal management of the life and death relation is taken up and debated in Kristin Savell's 'A Jurisprudence of Ambivalence: Three Legal Fictions Concerning Death and Dying'. Savell examines precisely the legal difficulties of when and under what conditions individuals might be granted a right to die. Through processes of legal examination individuals seeking a right to die must confront, not necessarily without ambivalence, the anticipated physical processes of their own death scene. In the absence of non-technologically mediated death scenes, the very idea of a natural death, Savell argues, is a problematic though not easily avoidable legal fiction. David Ellison and Isabel Karpin in 'Embryo Disposition and the New Death Scene' also examine the medical-legal nexus of the life and death relation. Ellison and Karpin's essay explores how technologies of reproduction have given rise to new rituals of grief, mourning and disposal of human or 'human potential', in this case surplus embryos in IVF clinics, and how women may opt to have them reimplanted in their bodies as a method of disposal. Their focus on this so-called 'compassionate transfer' as a memorial practice raises questions around the cultural and legal significance of the clinic as a provider of commemorative ritual.

Among the privileged classes in contemporary Western societies who share relatively good life expectation and abundant health and safety resources, there is an expectation that facing one's own death and those of loved ones is expected to be deferred till later life. Modern Western governance of health and hygiene, as well as the growth and development of medicine and technologies of life extension and support, and the resulting decline in infant mortality in the Western world, means that many children in these affluent circumstances are less likely to be exposed to death as a physical reality within their immediate social environments. This is in marked contrast to children raised in underprivileged societies characterised by 
war, civil unrest, food scarcity and water contamination. The shielding of many Western children from exposure to real life suffering and death scenes has led to an increasing mediation of death and dying by television, film and other media where death is known predominantly by its simulation. The comparative rarity of death and grief experience was particularly evident when the adventurer and animal conservationist Steve Irwin died in 2006. At this time, television and radio in Australia and elsewhere quickly produced a therapeutic discourse as experts advised parents on how best to explain and comfort children about Irwin's admittedly rather outlandish death. ${ }^{7}$ The alienation of real life death from privileged Western children's direct experience-its foreignness to the life and psyche of these children-meant that for many children in Australia and the United States, Steve Irwin's may well have been one of their first significant death and grief experiences.

The deferral of real life death experience makes death not just unfamiliar but positioned as external rather than always already internal within life itself. ${ }^{8}$ In other words, the shock of death when it erupts as an unexpected event is the result of its psychic and spatial sequestration from life and life spaces. In 'Death and Grief in the Landscape: Private memorials in Public Space', Margaret Gibson focuses on the largely absent and invisible aspect of death in most everyday environments of affluent and safe social and political geographies. Indeed, when the imagined boundary between life and death is spatially and symbolically breached by a bomb going off in a school yard, a shooting in a shopping mall or even a heart-attack on the street, the imagined 'death free zones' of these ordinary, everyday spaces are disturbingly put into question. Gibson's article examines the symbolic and political aspects of marking death and grief, particularly private grief, in the landscape and public spaces.

The representation of death and dying as a way of communicating moral truths is a common technique in almost all human cultures and societies. Western cultural traditions have been profoundly shaped by scenes of death as media for moral or spiritual instruction (think of Socrates or Jesus). Representations of the scene of death thus imbue an immanent and a transcendent meaning. The representation of death renders death meaningful to the living, by ascribing meaning or purpose. The transcendental meaning of such representations is that death also brings us in touch with that which cannot be comprehended, the divine 
and the sacred. This is particularly so when considering the historical place of the Christian guidebook of the art of dying well, known as the Ars Moriendi. In fifteenthcentury Europe, the Council of Constance commissioned this book depicting scenarios of the good and bad Christian death. Its purpose was not only to remind Christians of the danger of their soul's final capture by the devil if they led a sinful life, but to prepare them for a manner of spiritual conduct and resistance to evil in the last moments of their soul's life on earth. ${ }^{9}$ The handbook depicted images of angels and saints hovering above and demons lurking below the bedside of the dying Christian 'everyman'. The Ars Moriendi is more than a reminder of the Catholic Church's claim to moral and spiritual authority in Early Modern Europe. It is a powerful symbol of a now distant sensibility of the death scene as a threshold at once distinguishing and joining the visible physical world and an invisible but no less real and always present spiritual world. The death scenes of the Ars Moriendi thus encompass moral instruction and spiritual warning to prepare for one's inevitable crossing of that threshold. The dead might argue their successful passage via sepulchral sculpture depicting the entombed not in life, nor at rest, but rather in processual death. Countless gisants and transi tombs depicting decomposing corpses offer an emphatic reminder of death as well as contemptuous disregard for the flesh left here among the living.

Even in the age of secularisation, the representation of death continues as a medium of instruction. ${ }^{10}$ Consider Nietzsche's provocative announcement that 'God is dead'. Nietzsche's announcement is not so much a 'death scene' as a death notice; an obituary for the divine. Nietzsche announces the death of God through the words of 'The Madman' who accosts the ordinary people in the marketplace, almost as Socrates had done in ancient Athens, by asking 'Where is God?' and answering:

We have killed him-you and I. All of us are his murderers ... God is dead. God remains dead. And we have killed him. How shall we comfort ourselves, the murderers of all murderers? What was holiest and mightiest of all that the world has yet owned bled to death under our knives: who will wipe this blood off us? What water is there for us to clean ourselves? What festivals of atonement, what sacred games shall we have to invent? Is not the greatness of this deed too great for us? Must we ourselves not become gods simply to appear worthy of it? There has never been a 
greater deed; and whoever is born after us-for the sake of this deed he will belong to a higher history than all history hitherto. ${ }^{11}$

Nietzsche's 'madman' strikes almost the same tone as Plato contemplating Socrates' death. God is dead and we are all bereft. But Nietzsche's madman brings his message to the marketplace and accuses God's killers. This is the message that cannot be heard, or will not be understood but scorned by his listeners. It is the cold rationalism of science or the smug indifference of the masses that have killed God, have rendered the sacred defunct. But Nietzsche's purpose is not to grieve, but to fulfil. God is not to be mourned, neither is atonement through 'invented' rituals to be sought. Rather, God's death is a responsibility that must be owned in order for humans to become gods themselves. The moral message of Nietzsche's announcement is that we must found morality, truth and wisdom anew on the solid foundation of the 'will to power', instead of discredited notions of a divine order.

In using the representation of death to draw a moral lesson, Nietzsche's seemingly radical announcement conforms to a remarkably fruitful topos in Western thought. In the two iconic representations of death in Western culture, the deaths of Socrates and Jesus, the scene of each death is carefully set (by Plato and the Apostles respectively) in order to show triumph in death. In his Phaedo Socrates' pupil and admirer, Plato, records the death of his teacher following his 'conviction' by the government of Athens for 'corrupting the young'. For Plato, however, Socrates was much more than a victim of a politically inspired show trial. As Plato presents it Socrates dies not only for his polis, dutifully accepting his capital sentence, he dies for the sake of philosophy and wisdom. Plato underscores the point as the Phaedo nears its tragic conclusion by means of a double substitution-Socrates' temporary absence for his final death; Socrates' followers and pupils for his family. He uses Socrates' temporary withdrawal (to bathe and bid farewell to his own family) as a symbol of and prelude to his real impending death. Plato's message is that he and Socrates' other pupils and followers are the bereaved:

So we waited, discussing and reviewing what had been said, or else dwelling on the greatness of the calamity which had befallen us; for we felt as though we were losing a father and should be orphans for the rest of our lives. ${ }^{12}$ 
Plato's Socrates is calm in the face of death, and his willing acceptance of the judgment of the court is represented as wisdom and justice rather than folly. In his Crito, Plato has Socrates spurn the arguments of Crito that he should escape prison and avoid his sentence. Socrates' response is that to do so would undermine the laws, and strike at the very heart of the paternal relationship between polis and citizen. ${ }^{13}$ Plato's Socrates returns to the theme in Phaedo by means of another substitution. This time delay serves as a substitute for exile, and death is thereby represented as the burden of wisdom and philosophy. As Plato records it, Crito invites Socrates to put off taking the poison because the sun has not yet risen and in the meantime he may eat and drink and enjoy good company. Socrates' response echoes his earlier rejection of the invitation to escape in Crito. Socrates' final lesson in ethics took this form; they who delay their fate 'think that they gain by it', but Socrates said:

I should not; because I believe that that I should gain nothing by drinking the poison a little later-I should only make myself ridiculous in my own eyes if I clung to life and hugged it when it has no more to offer. ${ }^{14}$

Here the death scene is represented as triumph. The human Socrates ends his life but in doing so philosophy and ethics triumph over ignorance. These two elements of the death scene are woven together by Plato in such a way as to leave the reader in no doubt as to the great moral question that Socrates posed by his death. Now that I am gone, who of you will take up the burden of philosophy? The search for truth and wisdom, for justice and the good led Socrates to an untimely death. Plato records the scene not only to mourn a great loss, but to invoke a vision of philosophy as a quest without limit, and a vocation without reservation.

For early Christians this message could be recast in terms of the death of Jesus Christ, for many of whom the death of Socrates seemed a significant parallel. Both were venerated as good deaths symbolic of the triumph of truth, wisdom and love over falsity, ignorance and pain. ${ }^{15}$ Both were also deaths accepted, deaths that each were invited to escape. Central to the Apostles' depiction of Jesus' death is the mockery he receives on the cross. Thus Matthew:

And those who passed by derided him, wagging their heads and saying, 'You who would destroy the temple and rebuild it in three days, save yourself! If you are the Son of God, come down from the cross.' So also the 
chief priests, with the scribes and elders, mocked him, saying, 'He saved others; he cannot save himself. He is the King of Israel; let him come down now from the cross, and we will believe in him. He trusts in God; let God deliver him now, if he desires him. For he said, 'I am the Son of God.' (Matthew 27) ${ }^{16}$

In Luke however, another crucial dimension is added to the death scene, and that is the promise of redemption given by Jesus to one of the two criminals crucified with him in the face of such mockery:

One of the criminals who were hanged railed at him, saying, 'Are you not the Christ? Save yourself and us!'

But the other rebuked him, saying, 'Do you not fear God, since you are under the same sentence of condemnation?

And we indeed justly, for we are receiving the due reward of our deeds; but this man has done nothing wrong.'

And he said, 'Jesus, remember me when you come into your kingdom.'

And he said to him, Truly, I say to you, today you will be with me in Paradise.' $^{17}$

In the Christian tradition, this scene of death is inscribed with multiple meaning. At one level it marks the death of the human Jesus. It is in this sense a necessary prelude to the fulfilment of the divine bond to redeem human sin through the resurrection of Christ. As such this death scene serves as both warning and promise. Luke's 'second criminal' upon the cross rebukes the 'first criminal'; God must be feared, the innocence of Jesus must be acknowledged, and only in having done so is the promise of eternal life made possible. The death scene may also act as crux. Privileging the example of Christ's life over the promise of his death and resurrection produces markedly different, if not opposing, versions of the faith.

Two of the most familiar representations of death in Western culture are, in effect, vehicles of moral (and spiritual) instruction. Representations of death and dying have consistently been used in this way in Western philosophy and art ever since. Three of our contributors explore this theme in very different ways. Felicity Harley McGowan examines a most striking early visual representation of Christ's death in the Maskell Ivories. The images on the ivories reinforce the message of resurrection by contrasting a robust, indeed glorious, Jesus dying upon the cross in 
the eyes of God, with the bitter and unredeemed death of Judas. In her pictorial essay 'Obituary', Polly Gould reflects on the representation of death as a gesture to the sublime. Death in the landscape underscores the monumentality of nature, and points to both the beauty and horror of the sublime. The weakness of human beings, the insecurity of life in the 'state of nature', and the incessant quest for security is explored by Bruce Buchan's in 'Dying for Security'. Here, too, a representation of a scene of death, in this case Thomas Hobbes's account of the death of the commonwealth, is used to convey a political message; that the quest for security is premised on the perpetual fear of insecurity.

In the twenty-first century West, death's presence to sight and feeling is narratively framed and given to experience predominantly through the technology of the camera. Indeed the camera, its ownership and usage amongst a mass global population has reorganised where and how scenes of dying and death are seen and who or what makes this possible. For example, the execution of Saddam Hussein in Iraq by hanging in December 2006 was secretly recorded on a small, easily hidden camera by one or more officials in attendance. While his execution was not meant for public viewing, it is now freely available as part of the borderless social documentation of the internet archive. The camera, the lens and its magnification through various technologies (including the microscope), the computer and the digital archive all importantly constitute the forensics of twenty-first-century death scenes. Older forms of technology, such as photography and home movies, sentence the dead to a form of poignant restriction, their elusive features and gestures carefully transcribed but also immovably fixed in time. Quite the opposite is true of the dead who, via the internet, continue to live digitised, archival, even active lives. Social network sites such as FaceBook currently face the awkward problem of deceased members who continue to make their presence felt, thanks to social algorithms that prompt users to reconnect with friends who have died. One of the challenges faced by companies such as FaceBook is teaching their software to acknowledge the meaning of death. ${ }^{18}$

The deprivatisation of real life dying and its commodification, particularly in relation to celebrity, is another central feature of technologically produced and mediated death culture. The death scenes which have featured so prominently in the imagination of the Western world-J.F. Kennedy's assassination while travelling in a 
car, Princess Diana's death scene in a car crash, the toppling of the twin towers in New York in 2001, Michael Jackson's pharmacologically induced death-are significant death scenes of collective memory that mark out generational identities across nation-states and cultures. On sites such as YouTube, individuals post web diaries giving updates on their terminal illness, such as the Hollywood celebrity Farrah Fawcett's regularly published video diaries of her terminal illness in 2009. This public sharing of personal experience of dying and bereavement is now a common feature of late modernity. The boundary between public and private life is increasingly blurred and contested as a false dichotomy in an age where technological mediation of life and death is ubiquitous. When Steve Irwin died unexpectedly from a stingray barb while filming in Northern Queensland, the media wanted footage of his death scene to be released for public viewing. That his moment of death was recorded on camera, albeit as part of a documentary film, made the very idea of not releasing this footage for public viewing or consumption in the immediate aftermath seem like a curious, censorious decision. Furthermore, Irwin's place of 'rest' or 'burial' was also excluded from public knowledge by his family, preventing a site of pilgrimage and also, arguably, consolidating Australia Zoo as the key or surrogate site. The deprivatisation of death and dying in a technologically mediated, entertainment-based news culture is part of a broader historical condition of deprivatisation that is celebrity, YouTube broadcasting, and social networking culture.

The essays in this issue share an understanding that death is an event with a complex and even contradictory history; as something humans have variously embraced or disavowed depending on shifting notions of privacy and revelation. As a group, the essays argue for the importance of the death scene as a sensitive index to the way in which cultures make sense of endings. As to our own moment, the institutions that manage life's end, such as nursing homes and hospices, are charged with the responsibility of delivering 'a good death'. In 2000, the British Medical Journal $(B M J)$ published an editorial that listed the twelve principles underlying a good death. Among others these include:

To be able to retain control of what happens;

To be afforded dignity and privacy; 
To have choice and control over where death occurs (at home or elsewhere);

To have access to information and expertise of whatever kind is necessary;

To have access to any spiritual or emotional support required;

To have control over who is present and who shares the end. ${ }^{19}$

Overwhelmingly, these points privilege factors that illness and dying would seem to negate-choice, autonomy, control and independence. In other words, a positive death experience is assembled from qualities associated with notionally successful life as experienced in the contemporary West. As such, the $B M J$ offers what is in fact an extremely old idea couched in modern language; a return to the death scene as the apotheotic expression of an individual life.

-NOTES

The essays in the 'Death Scene' section of this issue were all originally presented as papers at two symposia: 'Death Scenes: Perspectives on Mortality' (Griffith University, 15-16 July 2009), and 'Interrogating Death and Dying: Legal, Biomedical and Social Perspectives' (University of Sydney, 6 November 2009). We would like to thank Professor Andy Bennett, Director of the Griffith Centre for Cultural Research, Griffith University, for generously supporting our Death Scenes'symposium. Thanks also to the Socio-Legal Research Centre at Griffith University for their support. Many thanks also to Professor Anna Haebich, and the State Library of Queensland for hosting the symposium. We are heartily grateful for all the administrative support from Jill Jones and Sarah Gornall at GCCR, Susan Kukucka and the technical staff at SLQ. We also gratefully acknowledge the support of Isabel Karpin and Kristin Savell and the Sydney University Law School for running the Interrogating Death and Dying' event. Finally, many thanks also to John Frow, Katrina Schlunke and Ann Standish at CSR, to our referees who generously gave their time, and to all our participants for their insightful contributions and willing participation.

\footnotetext{
${ }^{1}$ Margaret Gibson, The Death Scene: Between Public and Private, Interior and Exterior, the Real and the Fictional', paper presented at the symposium 'Death Scenes: Perspectives on Mortality', Griffith University, 12-16 July 2009. Forthcoming, South Atlantic Quarterly, 2011.
} 
${ }^{2}$ Cited by H. Saxon Snell, Typical Examples of the General Hospitals in Various Countires, qtd in Chris Otter, The Victorian Eye: A Political History of Light and Vision in Britain, 1800-1910, University of Chicago Press, Chicago, p. 128.

${ }^{3}$ Philippe Aries, The Reversal of Death: Changes in Attitudes Toward Death in Western Societies', American Quarterly, vol. 26, no. 5, 1974.

${ }^{4}$ Walter Benjamin, The Storyteller: Reflections on the Works of Nikolai Leskov', in Illuminations: Essays and Reflections, ed. H. Arendt, Schocken Books, New York, 1968, p. 94.

${ }^{5}$ Michael Wheeler, Heaven, Hell and the Victorians, Cambridge University Press, Cambridge, 1994, p. 37.

${ }^{6}$ Alan Kellehear, A Social History of Dying, Cambridge University Press, Cambridge, 2001.

${ }^{7}$ See <http://dying.about.com/b/2006/09/10/talking-to-children-about-the-death-of-crocodilehunter-steve-irwina-teachable-moment.htm; http://www.squidoo.com/steve_irwin\#module9991922>.

${ }^{8}$ Conversely, life always already within death.

${ }^{9}$ See Robert Kastenbaum and Beatrice Kastenbuam (eds), Encyclopedia of Death, Oryx Press, Arizona, 1989, Johann Gerhard, Handbook of Consolations: For the Fears and Trials that Oppress us in the Struggle with Death, trans. Carl L. Beckwith, Wipf and Stock Oregan, 2009.

${ }^{10}$ S. Bruce, God is Dead: Secularization in the West, Blackwell, Oxford, 2002.

11 Friedrich Nietzsche, The Gay Science $(1882,1887)$, ed. Bernard Williams, Cambridge University Press, Cambridge 2001, § 125, pp. 119-20

${ }^{12}$ Plato, Phaedo-Wisdom and the Soul, in The Last Days of Socrates, trans. H. Tredennick and H. Tarrant, Penguin, London, 1954, p. 196.

13 Plato, Crito-Justice and Duty, in The Last Days of Socrates, trans. H. Tredennick and H. Tarrant, Penguin, London, 1954, pp. 81-91.

14 Plato, Phaedo, p. 197.

${ }^{15}$ E.R. Wilson, The Death of Socrates, Profile Books, London, 2007, pp. 142-5.

${ }_{16}$ Matthew 27, The Bible, English standard version, online $<$ http://www.gnpcb.org/esv/search/?q=Luke+23> (accessed 25 March 2010).

17 Luke 23, The Bible, English standard version, online <http://www.gnpcb.org/esv/search/?q=Luke+23> (accessed 25 March 2010).

18 'As Facebook Users Die, Ghosts Reach Out', New York Times, 17 July 2010

<http://www.nytimes.com/2010/07/18/technology/18death.html?src=busln> (accessed 29 August 2010).

${ }^{19}$ BMJ, vol. 320, no. 129, 2000, online <http://www.bmj.com/content/320/7228/129.full> (accessed 27 August 2010). 